\title{
Risk factors at the travel destination: their impact on air travel satisfaction and repurchase intention
}

\author{
Myungsook An $\cdot$ Chongho Lee $\cdot$ Yonghwi Noh
}

Received: 17 October 2009/Accepted: 5 March 2010/Published online: 26 March 2010

(C) Springer-Verlag 2010

\begin{abstract}
The purpose of this study is to investigate the impact of four travel risk factors (natural disaster risk, physical risk, political risk, and performance risk) on traveler groups with different characteristics and the relationship among these risk factors, travel satisfaction, and travelers' repurchase intention. For the research purpose, this study analyzed the data from passengers of a major international airline. The results suggest that traveler groups with different characteristics (gender, airline seat class, travel purpose, travel destination, travel duration, travel companion, and income level) respond differently to some risk factors, while they show the same response to other risk factors. The results also show that each risk factor affects travel satisfaction and repurchase intention differently. These findings imply that airlines should develop different strategies based on risk factors and travelers' characteristics.
\end{abstract}

Keywords Perceived travel risk - Travel satisfaction - Repurchase intention · Air travel service

\section{Introduction}

Since the deregulation, the airline industry has become one of the most fiercely competitive industries. To develop competitive advantage, airline companies have

M. An · Y. Noh $(\bowtie)$

209 Department of Management, College of Business Administration, University of Nebraska,

P.O. Box 880491, Lincoln, NE 68588-0491, USA

e-mail: acipco@hanmail.net

M. An

e-mail: sigechu@hanmail.net

C. Lee

Korea Aerospace University, Hanggongdae-gil 100, Hwajon-dong, Dukyang-gu, Koyang-si, Kyonggi-do 412-791, South Korea

e-mail: skycrew@hanmail.net 
tried to improve their service quality for passenger satisfaction. As a result, many researchers have investigated critical factors affecting airline passengers' satisfaction and repurchase intention (Ostrowski 1993; Sultan and Simpson 2000; Tsaur et al. 2002; Chang 2003; Mazzeo 2003; Park et al. 2004; Ito and Lee 2004; Chen and Chang 2005; Lioua and Tzeng 2007; Bruecknera and Girvin 2008; An and Noh 2009). However, there is a paucity of research on the influence of perceived risk of the travel destination as a critical factor which affects passengers' travel decisions. This article investigates the impact of the perceived risk factors on travel satisfaction and repurchase intention to provide an insight for airlines' strategic planning.

Traveler safety has recently become a significant issue as travelers are increasingly concerned about risk factors at travel destinations. In fact, mass media have reported many disasters during the past 10 years such as earthquakes in Haiti and Chile, Indonesia tsunami, kidnappings in Afghanistan and Iraq, and various types of terrorism. According to World Tourism Organization (WTO 2003), travels to countries where avian influenza has appeared have decreased significantly. In the areas affected by the Indonesia tsunami in 2004, the number of visitors decreased dramatically after the catastrophe. Therefore, all the countries and major travel destinations strive to project a good image about safety to attract potential travelers.

Pizam and Tarlow (1997) stated that the crime and aggressive behaviors against travelers happen every minute in travel destinations all over the world. Nevertheless, the travel industry is expected to steadily grow in the long run. WTO (2003) predicted that the number of international travelers will reach about 1.05 billion in 2010 , and 1.6 billion by 2020, and the interchange of people among countries will continuously expand. In addition, the purpose of travel has become diversified into various types such as vacation, conferences, culture experiencing, leisure-sports, and history tourism. In order to properly manage a variety of growing demands for travel and tourism, airlines should be able to understand the impact of risk factors at travel destinations. In this light, this article investigates the relationship among risk factors, travel satisfaction, and repurchase intention.

This article is organized as follows: In Sect. 2, a brief literature review is presented on perceived risk, travel satisfaction, and repurchase intention. Then, a theoretical model to identify the impact of risk factors is developed based on previous research. The data collection process from passengers of one of the major international airline firms is presented. Data analysis results are presented concerning the impact of risk factors at destinations according to various characteristics of travelers and the relationships among these risk factors, travel satisfaction, and repurchase intention. Finally, we conclude this article with the implications of the results, limitations of the study, and future research needs.

\section{Literature review}

\subsection{Perceived risk}

Perceived risk was first defined by Bauer (1960) in the field of customer behavior. According to Bauer (1960), perceived risk is the subjectively discerned risk in a 
Table 1 Concepts of perceived risk

\begin{tabular}{ll}
\hline Researcher & Concept \\
\hline Bauer (1960) & $\begin{array}{l}\text { Subjectively discerned risk in the situation where customers need to select a } \\
\text { choice such as a brand, store, and way of purchase } \\
\text { Perceived risk is subject to intrinsic risk and its quantity, due to the fact that } \\
\text { customers cannot be confident of accomplishing the goal of purchase }\end{array}$ \\
$\begin{array}{l}\text { Cox (1967) } \\
\text { Angel and Blackwell amount of risk in purchase of a desired product }\end{array}$ \\
$\begin{array}{l}\text { Gartner (1989) } \\
\text { Assael (1995) }\end{array}$ & $\begin{array}{l}\text { Expected loss as a result of selection } \\
\text { A dilemma between desire to purchase and uncertain loss from the purchase }\end{array}$ \\
\hline
\end{tabular}

situation where customers need to make a choice for a brand, store, and way of purchase. In other words, perceived risk comes from uncertainty of a decision's outcome. Therefore, the customer's purchase and selection decision can result in unpredicted results and sometimes leads to negative consequences because of the uncertainty (Assael 1995).

Cox (1967) stated that perceived risk is subject to intrinsic risk and its quantity, and it is perceived because customers cannot be confident that their decisions would accomplish the goal of purchase. Engel and Blackwell (1983) defined perceived risk as the amount of risk involved in the purchase of a product, and Assael (1995) described it as a dilemma between the desire to purchase and an uncertain loss from the purchase. On the other hand, Gartner (1989) considered perceived risk as the expected loss and its negative effect as a result of selection. Table 1 presents the various concepts of perceived risk by different researchers.

Since Bauer's (1960) work, there has been a little discordance in approaches to explain the concept of perceived risk among researchers. However, these different views of the concept of perceived risk still consider it as an expectation or importance of loss as a result of choice with uncertainty (Stone and Winter 1987; Roehl and Fesenmaier 1992; Sonmez and Graefe 1998; Lee and Sah 2001). That is, even though researchers explain the concept of perceived risk in slightly different ways, the components of perceived risk are described consistently. The perceived risk at a travel destination plays a crucial role in the traveler's decision making (Roehl and Fesenmaier 1992; Sonmez and Graefe 1998). In fact, travelers have no choice but judge the risk at travel destinations from the available information because they cannot experience the actual situation of safety before arriving at the destination.

\subsection{Types of perceived risk}

Many researchers have investigated the impact of different types of perceived risk on customer behavior. The classification of perceived risk by Jacoby and Kaplan (1972) has been most widely applied to research on customer behavior. They classified the perceived risk into six types (financial risk, performance risk, physical risk, psychological risk, social risk, and time risk). In the field of tourism, Mayo and 
Jarvis (1981) classified the perceived risk into functional risk and psychological risk; and Moutinho (1987) classified them into functional risk, physical risk, financial risk, social risk, and psychological risk. Roehl and Fesenmaier (1992) classified perceived risk into seven types in investigating the relationship between perceived risk and vacation (performance risk, financial risk, physical risk, psychological risk, satisfaction risk, social risk, and time risk).

Tsaur et al. (1997) defined a traveler's perceived risk as a possible negative situation at the travel destination and divided it into physical and equipment risk on the basis of six evaluation standards (transportation, public security, sanitation, accommodation, weather condition, and travel place). Sonmez and Graefe (1998) added political risk and terror risk to seven types of Roehl and Fesenmaier (1992), and investigated customers' response to their purchase experiences based on those nine types. This article identifies risk types based on Sonmez and Graefe's (1998) study because the significance of political and terror risk is currently growing all over the world.

According to Sonmez and Graefe (1998), performance risk comes from the difference between travel cost and value of opportunity cost and it is related to quality of travel. Financial risk comes from the probability of unpredicted monetary loss or cost increase such as additional cost incurred and unplanned guide tip. Physical risk involves the possibility to be physically harmed during travel. The possibility of terrorism, accidents, and various diseases such as Severe Acute Respiratory Syndrome (SARS), Human Immunodeficiency Virus (HIV), cholera, an endemic disease, etc., significantly affect physical risk. Political risk comes from instability of politics or social disorder in a country. Social risk is a feeling of uneasiness about the possibility of being in trouble from the undeveloped technology level at a travel destination. Psychological risk is about the possible negative effect on the traveler's characteristics or personality caused by travel experiences. Terror risk is the probability of terrorism at a travel destination, and satisfaction risk is about the gap perceived between the expected and actual level of satisfaction with the travel. Time risk is a sense of uneasiness about the limitation of time on the travel schedule.

\subsection{Travel satisfaction and repurchase intention}

Travelers evaluate their previous decisions about travel based on the level of their satisfaction or dissatisfaction with travel destinations and decide whether to revisit the place or not. Travelers usually have different responses about their travel experience, and the level of satisfaction might also be different even though they had the same travel. Research on customer satisfaction has generally been done based on the expectation-performance inconsistency theory of Oliver (1980), focusing on theoretically critical factors of satisfaction. In this theory, customer satisfaction can be evaluated by the difference between expectation and performance. The expectation-performance inconsistency approach has been widely used in studies on travelers' satisfaction (Sonmez and Graefe 1998). In this light, the level of perceived risk before travel can be seen as a gap between expectation and 
the level of perceived performance, on the basis of which travel satisfaction can be evaluated (Raaij and Francken 1984).

Oliver and Bearden (1985) argued that there is a positive relationship between customer satisfaction and repurchase intention and this relationship is nonlinear. Cronin and Taylor (1992) stated that customer satisfaction has a high level of relationship with repurchase intention regarding fast food, bank, and laundry services. In a tourism context, Tian (1998) showed that a travelers' satisfaction of the overall service quality directly affects repurchase intention and future travel behavior. A high level of perceived risk also negatively influences repurchase intention by decreasing a traveler's satisfaction (Wirtz and Mattila 2001). Based on these previous studies, this study investigates how various types of perceived risks influence a traveler's satisfaction and future behavior.

\section{Research design and methodology}

\subsection{Research model}

The purpose of this study is to discern how different types of travel risk are perceived by travelers with different characteristics, and to investigate the relationship among the perceived risk factors, customer satisfaction, and repurchase intention. Figure 1 presents the research model.

\subsection{Definition of variables}

This study adopted three risk types (physical risk, political risk, and performance risk) from Sonmez and Graefe's (1998) research, because theses three types are considered as critical factors which affect airlines' performance based on interviews with specialists in the airline industry. In addition, we developed natural disaster risk as a new risk type, considering travelers' growing anxiety about this type of risk. The research variables are defined as follows:

(1) Natural disaster risk: the probability of natural disasters such as earthquake, tsunami, flood, and volcano eruption.

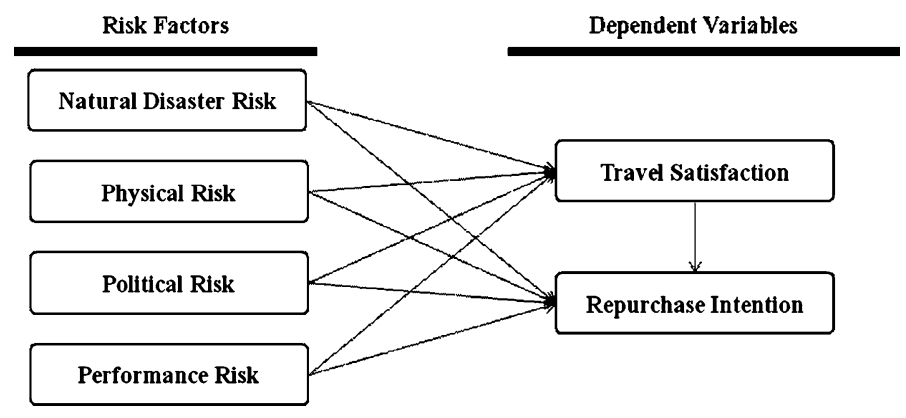

Fig. 1 Research model 
(2) Physical risk: the possibility to be physically harmed during travel from disease, accident, terrorism, etc.

(3) Political risk: the perceived degree of instability of the political condition at the travel destination.

(4) Performance risk: the perceived degree of the difference between travel cost and value of opportunity cost.

A questionnaire was developed according to the definitions of the variables above. The questions to measure each variable were based on five-point Likert scale. Travel satisfaction is based on the traveler's perception about the quality and performance of travel, which is emotional response of the traveler's experience. Repurchase intention is the desire to revisit the travel destination or reuse a tour package, which includes the willingness to recommend the same type of travel to acquaintances.

\subsection{Instrument design}

To evaluate the influence of perceived risk factors, we developed 10 items for risk factors and 3 items for customer satisfaction and repurchase intention. We also developed 10 items to evaluate the demographical information of the sample group. All items were based on five-point Likert scale except for demographics items.

\subsection{Sample and data collection}

The data were collected from passengers of a major international airline company in South Korea. Despite the fact that passengers' expectations and perceptions can vary according to nationality as presented by Sultan and Simpson (2000), this airline is a model company of the global airline industry in terms of its size and business scale. All questionnaires were collected from passengers using international routes. A total of 270 questionnaires were collected and 253 questionnaires were used in this study after excluding 17 incomplete questionnaires. Collecting data from air passengers is extremely difficult as airlines have strict rules for not disturbing the customers. A special permission was received for this study from the firm.

\subsection{Data analysis}

To examine the traveler's perception of different risk factors and investigate the relationships among risk factors, travel satisfaction, and repurchase intention, various statistical tools were used. First, frequency analysis was employed to get the demographic information of the sample. Second, factor and reliability analyses were performed to identify the risk factors which affect the traveler's satisfaction and repurchase intention. Third, $t$ test and ANOVA were applied to investigate how travelers perceive different risk factors according to different traveler characteristics. Finally, regression analysis was employed to investigate the impact of various risk factors on travel satisfaction and repurchase intention. 


\section{Result and discussion}

\subsection{Demographic characteristics of the sample group}

As shown in Table 2, the sample was classified by gender, age, and travel purpose. The gender ratio shows that the number of female respondents is slightly higher than that of male respondents. The majority of respondents in the sample are in the 21-50 age group (82.6\%). The main travel purpose is vacation/leisure, followed by business and education/visiting.

\subsection{Factor analysis and reliability analysis}

To test unidimensionality of variables, factor analysis was employed. As factorloading values were over 0.6 , which is a general standard for unidimensionality, the variables passed the unidimensionality test. From the Cronbach alpha values, shown in Table 3, reliabilities of all variables are assured because they are all above 0.7.

Table 2 Sample demographics

\begin{tabular}{lcr}
\hline Demographic characteristics & Frequency & Percent \\
\hline Gender & 111 & \\
Male & 142 & 43.9 \\
Female & & 56.1 \\
Age & 8 & \\
Under 25 & 67 & 3.2 \\
$21-30$ & 81 & 26.5 \\
$31-40$ & 61 & 32.0 \\
$41-50$ & 36 & 24.1 \\
Over 50 & & 14.2 \\
Travel purpose & 83 & \\
Business & 153 & 32.8 \\
Vacation/leisure & 17 & 60.5 \\
Education/visiting & 253 & 6.7 \\
Total & & 100.0 \\
\hline
\end{tabular}

Table 3 Results of factor analysis and reliability analysis

* Travel satisfaction has only one item

\begin{tabular}{lll}
\hline & Variance ratio & Cronbach alpha \\
\hline Natural disaster risk & 87.49 & 0.8564 \\
Physical risk & 67.01 & 0.7479 \\
Political risk & 62.54 & 0.6995 \\
Performance risk & 78.22 & 0.7214 \\
Travel satisfaction & $-*$ & 0.7200 \\
Repurchase intention & 78.13 & 0.7200 \\
\hline
\end{tabular}




\section{$4.3 t$ test and ANOVA}

This study employed $t$ test and one-way ANOVA to investigate how travelers perceive different types of risk according to seven passenger characteristics (gender, airline seat class, travel purpose, travel destination, travel duration, travel companion, and income level). The results of $t$ test and ANOVA are summarized in Table 4.

In recognition of travel risk factors, male and female respondents show no significant difference for all risk factors. In addition, they show no significant difference in travel satisfaction and repurchase intention. According to $t$ test based on airline seat class (business class vs. economy class), business class passengers evaluate the political risk more significantly than economy class passengers. The reason is conjectured that passengers with relatively high income might be more concerned about the political stability at the travel destination. There is no difference between business and economy class passengers regarding other risk factors, travel satisfaction, and repurchase intention.

In ANOVA to investigate how travelers perceive risk factors vis-à-vis travel purposes (business, vacation/leisure, and education/visiting), no significant difference was found among different travel purposes, travel satisfaction, and repurchase intention. As for the travel destination, five different travel destinations (Southeast Asia, North America, Europe, Oceania, and others) were used for ANOVA. In this analysis, significant differences were found in political risk and repurchase intention. The reason for this might be that travelers perceive political risk quite differently according to travel destinations and their repurchase behaviors appears to be sensitive to travel cost which is subject to distance to travel destinations.

For travel duration, three different periods (1-4 days, 5-7 days, and over 7 days) were analyzed by ANOVA. Significant differences were found for natural disaster risk and physical risk. The result might be due to the increasing exposure to natural disasters and physical risk when travel duration increases. As for travel companion,

Table 4 Results of $t$ test and ANOVA

\begin{tabular}{|c|c|c|c|c|c|c|c|}
\hline & \multicolumn{2}{|l|}{$t$ test } & \multicolumn{5}{|l|}{ ANOVA } \\
\hline & Gender & $\begin{array}{l}\text { Airline seat } \\
\text { class }\end{array}$ & $\begin{array}{l}\text { Travel } \\
\text { purpose }\end{array}$ & $\begin{array}{l}\text { Travel } \\
\text { destination }\end{array}$ & $\begin{array}{l}\text { Travel } \\
\text { duration }\end{array}$ & $\begin{array}{l}\text { Travel } \\
\text { companion }\end{array}$ & $\begin{array}{l}\text { Income } \\
\text { level }\end{array}$ \\
\hline $\begin{array}{l}\text { Natural } \\
\text { disaster risk }\end{array}$ & $\mathrm{X}$ & $\mathrm{X}$ & $X$ & $\mathrm{X}$ & $\mathrm{O}$ & $\mathrm{X}$ & $\mathrm{X}$ \\
\hline Physical risk & $\mathrm{X}$ & $\mathrm{X}$ & $X$ & $X$ & $\mathrm{O}$ & $\mathrm{X}$ & $X$ \\
\hline Political risk & $\mathrm{X}$ & $\mathrm{O}$ & $X$ & $\mathrm{O}$ & $\mathrm{X}$ & $\mathrm{X}$ & $X$ \\
\hline $\begin{array}{l}\text { Performance } \\
\text { risk }\end{array}$ & $X$ & $X$ & $X$ & $X$ & $\mathrm{X}$ & $X$ & $\mathrm{X}$ \\
\hline $\begin{array}{l}\text { Travel } \\
\text { satisfaction }\end{array}$ & $X$ & $\mathrm{X}$ & $X$ & $X$ & $\mathrm{X}$ & $X$ & $\mathrm{O}$ \\
\hline $\begin{array}{l}\text { Repurchase } \\
\text { intention }\end{array}$ & $\mathrm{X}$ & $X$ & $X$ & $\mathrm{O}$ & $\mathrm{X}$ & $X$ & $X$ \\
\hline
\end{tabular}

$X$ nonsignificant, $O$ significant relationship 
five different groups (alone, friend, colleague, lover, and family) were used for ANOVA, and these different travel companion groups showed no difference in four risk factors, travel satisfaction, and repurchase intention. For different income groups (under USD 20,000, USD 20,000-40,000, USD 40,000-60,000, USD 60,000-80,000, and over USD 80,000), no differences were found in four risk factors and repurchase intention, but travel satisfaction showed some difference. The reason might be that each income group evaluates the performance based on their previous travel experiences which would be quite different among income groups. It is highly probable that the high-income group might have more travel abroad experiences and thus more strict standards to evaluate the travel.

\subsection{Regression analysis}

The influence of four risk factors on travel satisfaction was analyzed by regression analysis as presented in Table 5. From the $F$ value of 126.737 and $p$ value of 0.000 , this regression equation is statistically significant. Performance risk most significantly affects travel satisfaction with a beta value of 0.465 , followed by physical risk with 0.305 , while natural disaster risk and political risk do not influence travel satisfaction. The variance in travel satisfaction explained by the regression model $\left(R^{2}\right)$ was 0.416 .

The impact of travel risk factors on repurchase intention was also analyzed by regression analysis as shown in Table 6 . This regression results were statistically significant with $R^{2}$ value of $0.424, F$ value of 107.693 , and $p$ value of 0.000 . Natural disaster risk affects repurchase intention most significantly with a beta value of 0.322 , and performance risk is second with 0.253 . Political risk also influences

Table 5 Results of regression analysis between risk factors and travel satisfaction

\begin{tabular}{|c|c|c|c|c|c|}
\hline \multirow[t]{2}{*}{ Variables } & \multicolumn{2}{|c|}{ Coefficient of non-std. } & \multirow{2}{*}{$\begin{array}{l}\text { Coefficient of std. } \\
\text { Beta }\end{array}$} & \multirow[t]{2}{*}{$t$} & \multirow[t]{2}{*}{ Sig. } \\
\hline & $B$ & SE & & & \\
\hline (Constant) & 3.119 & 0.048 & & 64.437 & 0.000 \\
\hline Performance risk & 0.468 & 0.052 & 0.465 & 8.929 & 0.000 \\
\hline Physical risk & 0.303 & 0.052 & 0.305 & 5.863 & 0.000 \\
\hline
\end{tabular}

$R^{2}=0.416, F=126.737, p$ value $=0.000$

Table 6 Results of regression analysis between risk factors and repurchase intention

\begin{tabular}{|c|c|c|c|c|c|}
\hline \multirow[t]{2}{*}{ Variables } & \multicolumn{2}{|c|}{ Coefficient of non-std. } & \multirow{2}{*}{$\begin{array}{l}\text { Coefficient of std. } \\
\text { Beta }\end{array}$} & \multirow[t]{2}{*}{$t$} & \multirow[t]{2}{*}{ Sig. } \\
\hline & $B$ & $\mathrm{SE}$ & & & \\
\hline (Constant) & $4.698 \mathrm{E}-03$ & 0.049 & & 0.097 & 0.923 \\
\hline Natural disaster risk & 0.326 & 0.056 & 0.322 & 5.832 & 0.000 \\
\hline Performance risk & 0.257 & 0.066 & 0.253 & 3.917 & 0.000 \\
\hline Political risk & 0.227 & 0.070 & 0.222 & 3.236 & 0.001 \\
\hline
\end{tabular}

$R^{2}=0.424, F=107.693, p$ value $=0.000$ 
Table 7 Results of regression analysis between travel satisfaction and repurchase intention

\begin{tabular}{|c|c|c|c|c|c|}
\hline \multirow[t]{2}{*}{ Variables } & \multicolumn{2}{|c|}{ Coefficient of non-std. } & \multirow{2}{*}{$\begin{array}{l}\text { Coefficient of std. } \\
\text { Beta }\end{array}$} & \multirow[t]{2}{*}{$t$} & \multirow[t]{2}{*}{ Sig. } \\
\hline & $B$ & SE & & & \\
\hline (Constant) & 3.125 & 0.053 & & 58.939 & 0.000 \\
\hline Travel satisfaction & 0.539 & 0.053 & 0.544 & 10.272 & 0.000 \\
\hline
\end{tabular}

$R^{2}=0.296, F=105.523, p$ value $=0.000$

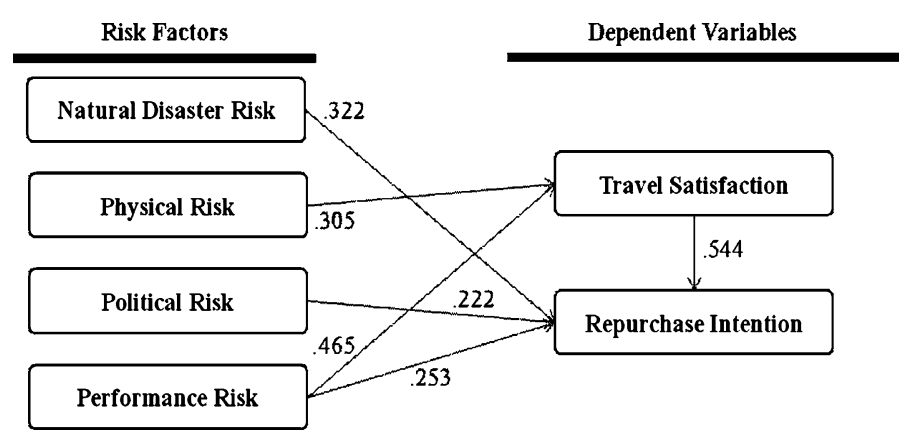

Fig. 2 Summary of regression analyses (beta values)

repurchase intention with a beta value of 0.222 , while physical risk has no significant influence.

Finally, we performed regression analysis to examine the relationship between travel satisfaction and repurchase intention. As shown in Table 7, travel satisfaction significantly affects repurchase intention with an $F$ value of 105.523 and a $p$ value of 0.000 . The beta value of travel satisfaction was 0.544 and $R^{2}$ was 0.296 . The results of regression analyses are summarized in Fig. 2.

\section{Conclusion}

This study adopted four risk factors (natural disaster risk, physical risk, political risk, and performance risk) as major risk types to affect travel satisfaction and the traveler's repurchase intention. The results of $t$ test and ANOVA showed that different traveler groups with different characteristics (gender, airline seat class, travel purpose, travel destination, travel period, travel companion, and income level) respond differently to some risk factors, while they show the same response to the other risk factors. Regression analysis identified the risk factors which affect travel satisfaction and repurchase intention.

Natural disaster risk functions as a critical factor for travelers who plan for a longer duration travels and affects their decision making to revisit. Physical risk is also a critical factor for travelers who plan to stay at a travel destination. Travelers with relatively high income tend to avoid travel destinations with high political risk, and travelers perceive political risk differently according to different areas in the 
world (Southeast Asia, North America, Europe, Oceania, and others). Performance risk does not show a significant difference among different travel groups.

Physical risk and performance risk significantly affect travel satisfaction, while natural disaster risk, political risk, and performance risk play crucial roles in revisit intention. Therefore, airlines should consider natural disaster risk, political risk, and performance risk more seriously than physical risk, when they plan flight routes. Especially, airlines should focus on performance risk at a travel destination because it significantly affects both travel satisfaction and repurchase intention.

This study has limitations with respect to external validity as the sample was collected from passengers of only one global airline company. In addition, all passengers in the sample were Koreans, and thus the results of this study may not be generalized for all passengers of different nationalities. However, we believe the results provide important insights to the airline service industry because this airline company is a major international airline with a global scale and air-routes.

This study classified traveler groups according to several characteristics and investigated responses of those groups' vis-à-vis risk factors. If we add additional traveler characteristics, more complex results could have been derived. In addition, application of these characteristics to other risk factors beyond the four risk factors examined in this study might provide additional insights into understanding travelers' behavior.

\section{References}

An M, Noh Y (2009) Airline customer satisfaction and loyalty: impact of in-flight service quality. Serv Bus Int J 3(3):293-307

Assael H (1995) Consumer behavior and marketing action, 5th edn. South-Western College Publishing, Cincinnati

Bauer RA (1960) Consumer behavior as risk taking. In: Hancock RS (ed) Proceedings of American Marketing Association, Chicago, IL, pp 389-398

Bruecknera J, Girvin R (2008) Airport noise regulation, airline service quality, and social welfare. Transp Res B 42(1):19-37

Chang D (2003) A comparative study of measuring air liners' service quality. J Korean Soc Qual Manag 31(4):36-54

Chen F, Chang Y (2005) Examining airline service quality from a process perspective. J Air Transp Manag 11(2):79-87

Cox DF (1967) Risk handling in consumer behavior-an intensive study of two cases, risk taking and information handling in consumer behaviors. Harvard University Press, Boston

Cronin JJ, Taylor SA (1992) Measuring service quality: a reexamination and extension. J Mark 56(3):5568

Engel JF, Blackwell RD (1983) Consumer behavior. The Dryden Press, Hinsdale

Gartner WC (1989) Tourism image: attibute measurement of state tourism products using multidimensional scaling techniques. J Travel Res 28(2):16-20

Ito H, Lee D (2004) Assessing the impact of the September 11 terrorist attacks on U.S. airline demand. J Econ Bus 57(1):75-95

Jacoby J, Kaplan V (1972) The components of perceived risk. Proceedings of the third annual conference of association for consumer research, vol 1, pp 98-118

Lee K, Sah J (2001) Risk perception in behavioral stages of consumption according to characteristics of tour packages and travelers. Res Travel Qual Syst 7(3):95-117

Lioua J, Tzeng G (2007) A non-additive model for evaluating airline service quality. J Air Transp Manag 13(3):131-138 
Mayo EJ, Jarvis LP (1981) The psychology of leisure travel. CBI, Boston

Mazzeo M (2003) Competition and service quality in the U.S. airline industry. Rev Ind Organ 22(4):275296

Moutinho L (1987) Consumer behavior in tourism. Eur J Mark 21(10):5-44

Oliver RL (1980) A cognitive model of the antecedents and consequences of satisfaction decision. J Mark Res 17(4):460-469

Oliver RL, Bearden WO (1985) Crossover effects in the theory of reasoned action: a moderating influence attempt. J Consum Res 12(3):324-340

Ostrowski P (1993) Service quality and customer loyalty in the commercial airline industry. J Travel Res 32(2):16-24

Park J, Robertson R, Wu C (2004) The effect of airline service quality on passengers' behavioral intentions: a Korean case study. J Air Transp Manag 10(6):435-439

Pizam A, Tarlow P (1997) Making tourists feel safe: whose responsibility is it? J Travel Res 36(1):23-28

Raaij WF, Francken DA (1984) Vacation decisions, activities, and satisfactions. Ann Tour Res 11(1):101-112

Roehl WS, Fesenmaier DR (1992) Risk perceptions and pleasure travel: an exploration analysis. J Travel Res 30(4):17-26

Sonmez SF, Graefe AR (1998) Influence of terrorism risk on foreign tourism. Ann Tour Res 25(1):112144

Stone RN, Winter FW (1987) Risk is it still uncertainty times consequences? Proceedings of American Marketing Association, Chicago, IL, pp 261-265

Sultan F, Simpson M (2000) International service variants: airline passenger expectations and perceptions of service quality. J Serv Mark 14(3):188-216

Tian S (1998) Testing efficiency of an attitudinal process model of relationship between service quality and visitor satisfaction in a tourism context. Doctoral Dissertation of Texas A\&M University, UMI

Tsaur S, Tzeng G, Wang K (1997) Evaluating tourist risks from fussy perspectives. Ann Travel Res 24(4):796-812

Tsaur S, Chang T, Yen C (2002) The evaluation of airline service quality by fuzzy MCDM. Tour Manag 23(2):107-115

Wirtz J, Mattila A (2001) Exploring the role of alternative perceived performance measures and needscongruency in the consumer satisfaction process. J Consum Psychol 11(3):181-192

World Tourism Organization (2003) The issue of safety. WTO 